Obituary …........................................................................

\title{
Walter Somerville CBE 1913-2005
}

$\mathrm{W}$ alter Somerville was born into a Roman Catholic family of modest means in Clontarf, just outside Dublin. He attended the prestigious Jesuit College-Belvedere. Prompted perhaps by the death of his mother from rheumatic heart disease, he trained as a doctor at The Mater Hospital. After house appointments and obtaining his MD in Dublin, he studied for the Membership at the Grosvenor Sanatorium in Kent. He had just accepted a junior appointment at St Mary's Hospital London when war was declared. Against advice of friends, he volunteered for service in the RAF. However, he was made to join the Army and sent on a troop ship to India. He did not want to become an Army doctor and was quickly recalled and posted to the Chemical Warfare Establishment at Porton Down. The unit moved to Suffield in Canada and he was seconded to the US Army where he was involved in development of chemical warfare on an island off Panama. As the war drew to an end, his unit was preparing an invasion of Japan, a mission from which it was not expected to return, but the Atomic Bomb came first. In 1945 he was awarded the Legion of Merit, USA and was given two years' medical training in America under the GI Bill of Rights. He worked with the new leading cardiologists, many of whom became life long friends including Frank Wilson and Sam Levine. During this time, he was invited by Metro-Goldwyn-Mayer to go to Hollywood-he declined the offer!

Shortly after returning to London in 1947, he attended a lecture by Paul Wood at Hammersmith Hospital. Afterwards he asked the only question which must have been a penetrating one because Wood invited him to become his assistant at the new Institute of Cardiology. Thus began a long, close friendship. In 1953, he was given consultant sessions at Harefield Hospital to support Sir Thomas Holmes Sellors who was pioneering open heart surgery under hypothermia, and in 1954 he joined the consultant staff at the Middlesex Hospital with Evan Bedford.

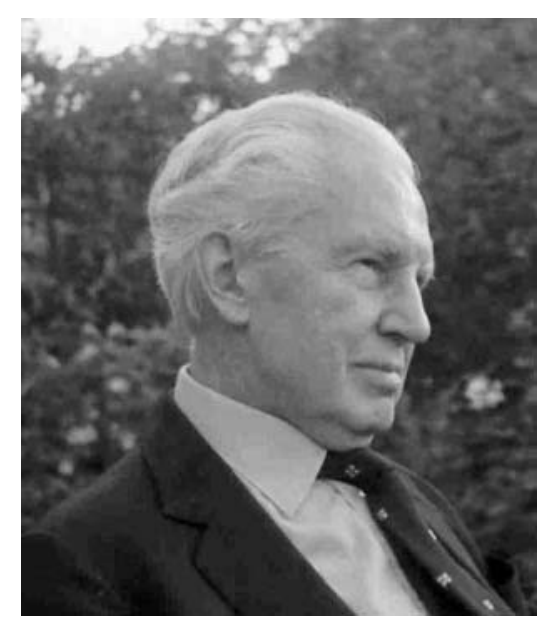

Walter was a popular teacher and the student's Christmas concerts usually included a sketch on "Walter" which never failed to feature his charm and his carnation.

In 1957 he married Jane Platnauer who, in her own right, is a cardiologist of international repute. He was immensely proud of her and their four children. The Somervilles were generous hosts and brought together, in their home in York House, young doctors and leading cardiologists from all over the world. He was editor of the British Heart Journal for 20 years and President of the British Cardiac Society from 1976 to 1981. He forged closer links with American and European Cardiac Societies and negotiated a new contract with BMA Publications which helped towards the purchase of 9, Fitzroy Square, now headquarters of the British Cardiac Society. Walter was the face of British cardiology throughout the world.

He continued with his hospital work, but there were ever increasing demands from patients world wide and he became quite fluent in Arabic. He was President of the British Academy of Forensic Sciences and was frequently called as an expert witness. Sadly, macular degeneration forced his retirement in the mid 1990s and he suffered a stroke, but continued to receive friends warmly and without self pity.

Walter was a man of integrity, always immaculately dressed, unhurried and in control. He was a master of the English language and an outstanding speaker. He had great presence and was a very able cardiologist, but perhaps his greatest strength was his ability to assess the whole patient and speak to the patient and family in simple terms that they could understand. Often he would be one of 10 or more world renowned cardiologists looking after a VIP. It was quite natural that he should take the lead and communicate with the patient, the family, and the press as the occasion demanded.

He was a life long diarist, recording the daily events of cardiology and life in general until two years before his death. He had wide interests outside medicine, and was extraordinarily well informed about diverse subjects. He played the piano, was trustee of the British Association of Performing Arts, loved horse racing and rugby (always supporting the Irish!). For many years he was deeply interested and educated in wine, enjoying the company of respected Vintners. He was the Treasurer of the Saintsbury Club, founded by Andre Simon.

He only needed five hours sleep, but it seems scarcely possible that he could pack so much into a day, always with endless time for patients. Even so, the smallest kindness would be rewarded with a letter of thanks the next morning, written in his elegant, legible hand.

In his early days, screening, the chest radiograph, and the ECG were the only "special investigations" available to the cardiologist. Diagnosis depended on highly developed bedside skills, especially auscultation. There were few cardiologists, they trained generations of students and young doctors, some were known nationally and internationally, and a few were giants in the profession. Walter was one of these, a giant-his death marks the end of an era of style and elegance in cardiology.

M Towers, R Emanuel 